\title{
EMPREGO DOS MÉTODOS ELETROMAGNÉTICO INDUTIVO E GPR NO MAPEAMENTO DE REDES DE INTERFERÊNCIAS INSTALADAS NO SÍTIO CONTROLADO DE GEOFÍSICA RASA DO IAG/USP
}

\author{
Vinicius Rafael Neris dos Santos \\ Orientador: Dr. Jorge Luís Porsani (IAG-USP) \\ 146 p. - Dissertação (Mestrado) - Defesa 19.03 .2009
}

\begin{abstract}
RESUMO. Nesta pesquisa foram realizados levantamentos geofísicos utilizando os métodos eletromagnético indutivo - EMI (equipamento EM38) e GPR - Ground Penetrating Radar, visando localizar redes de interferências, tais como, tubulações metálicas, cabos elétricos e conduítes de plástico instalados nas linhas 6 e 7 do Sítio Controlado de Geofísica Rasa do IAG/USP. Os dados EMI foram afetados pelo drift instrumental devido à variação de temperatura. A sua correção foi efetiva por meio do uso de uma função quadrática, realçando os alvos mais profundos. A aquisição em distância permitiu detectar alvos metálicos no subsolo com boa precisão e a aquisição em tempo permitiu fazer um mapeamento regional de alvos metálicos no subsolo. Os melhores resultados foram obtidos com a aquisição em distância, com os sensores posicionados a $10 \mathrm{~cm}$ de altura, devido às anomalias ficarem mais nítidas, onde a influência da condutividade do background foi reduzida. Os perfis GPR 2D obtidos com a antena de $400 \mathrm{MHz}$ permitiram detectar os alvos até $1 \mathrm{~m}$ de profundidade e com a antena de $200 \mathrm{MHz}$ foi possível detectar quase todos os alvos metálicos e não-metálicos instalados nas linhas estudas do SCGR. Para o GPR quase-3D, na forma de depth slices, foram importantes para estimar as dimensões dos alvos e melhorar a visualização dos resultados. Os resultados obtidos com os métodos EMI e GPR são complementares, sendo ambos recomendados no mapeamento de interferências no subsolo, tendo aplicações diretas nas áreas de planejamento urbano e infra-estrutura nos grandes centros urbanos.
\end{abstract}

ABSTRACT. This research inductive electromagnetic-EMI (EM38 equipment) and GPR - Ground Penetrating Radar methods were applied in order to locate interferences, such as steel pipes, electric cables and plastic conduit installed in lines 6 and 7 of test site of the IAG/USP. EMI data were affected by drift instrument due to temperature variation. The correction through the use of a quadratic function was effective, improving the deeper targets. The distance acquire data permit to identify steel targets in subsoil with good accuracy and time acquire permit to make a regional map of the steel targets in subsoil. The best results were obtained with the distance acquire data with the sensors placed at $10 \mathrm{~cm}$ in height, due to anomalies become more clear, where the influence of the background conductivity was reduced. The 2D GPR profiles obtained with $400 \mathrm{MHz}$ antenna permit to detect targets until $1 \mathrm{~m}$ depth and the $200 \mathrm{MHz}$ antenna permit to detect almost all metal targets and non-metallic installed in the study lines of test site. 3D GPR results in form of depth slices were important to estimate the size of the targets and improve the visualization of results. The results obtained with the EMI and GPR methods are complementary, and both are recommended in mapping interference in subsoil, with direct applications in the areas of urban planning and infrastructure in urban centers. 